\title{
Difusi Adopsi Teknologi Pendederan Ikan Patin pada Kelompok Pembudidaya Ikan di Kabupaten Purwakarta
}

\author{
[Diffusion of Technology Adoption of Patin Fishing on Fish Cultivation Group \\ in Purwakarta Regency] \\ Abdul Hanan ${ }^{凶}$ \\ Sekolah Tinggi Perikanan, Jurusan Penyuluhan Perikanan \\ Jalan Cikaret Nomor 1 Bogor 16001, Jawa Barat \\ Diterima: 20 Januari 2017; Disetujui: 16 Maret 2017
}

\begin{abstract}
Abstrak
Tujuan penelitian adalah menganalisis kecepatan penerapkan probiotik (Bakteri Lactobacillus) sebagai suatu inovasi pada pendeder ikan patin ditinjau dari aspek atribut inovasi dan atribut adopster. Difusi inovasi terkait dengan factor sugesti (pengaruh/kepercayaan), identifikasi (penelaahan) serta faktor imitasi (peniruan), dan ciri-ciri dari inovasi yang disampaikan, serta gencarnya promosi dari inovasi tersebut. Hasil kaji terap sebagai atribut inovasi $\mathrm{pH} 7,84$ dan DO 5,61, panjang ikan 7,81 cm, dengan berat 3,90, dengan SR 99,8\%, sedangkan tanpa probiotik panjang $5,17 \mathrm{~cm}$ dengan berat $1,16 \mathrm{gr}$, dengan SR $75 \%$. Sedangkan atribut pengadopsi ingkat peniruan oleh sasaran pada minggu ke 9 sejak diperkenalkan inovasi terdapat 10 orang, pada tarap kepercayaan 0,05 berkorelasi dengan pengalaman usaha $\left(0,399^{*}\right)$ dan keinovatifan sasaran $\left(0,395^{*}\right)$ pada tarap nyata 0,05 . Faktor pendifusi berkotrelasi dengan kredibiltas $\left(0,367^{*}\right)$ serta daya tarik $(0,389 *)$
\end{abstract}

Kata kunci: adopsi, difusi, Inovasi

\begin{abstract}
The aim of this research is to analyze the speed of applying probiotics (Lactobacillus bacteria) as an innovation on patine pendeder from aspects of innovation attributes and attributes of adopter. The diffusion of innovation is related to the factors of suggestion (influence / trust), identification (review) as well as the imitation factor (imitation), and the characteristics of the innovation delivered, and the incessant promotion of the innovation. The result of the study was applied as innovation atibut $\mathrm{pH} \mathrm{7,84}$ and DO 5,61, fish length 7,81 cm, weighing 3,90, with SR $99,8 \%$, while without probiotic length $5,17 \mathrm{~cm}$ with weight $1,16 \mathrm{gr}$, With SR $75 \%$. While the attribute of adopting imitation rate adopted by the target at 9th week since innovation was introduced there were 10 people, at 0.05 confidence taik correlated with business experience $(0,399 *)$ and innovation target $(0.395 *)$ in real taih 0.05 . The diffusing factor berkrelrelasi with kridibiltas $(0.367 *)$ as well as appeal $(0.389 *)$.
\end{abstract}

Keywords: adoption, diffusion, Innovation

\section{PENDAHULUAN}

Prinsip-prinsip difusi inovasi da-

lam penyuluhan perikanan terkait dengan

diproses teknologi baru sampai kesasaran

$\square$ Penulis korespondensi

Alamat surel: abdulhanan278@gmail..com penyuluhan yaitu pelaku usaha. Aspek yang terkait dengan proses difusi yaitu teknologi inovatif dan rentang waktu dan daerah atau sasaran. Suatu teknologi dianggap inovatif di suatu daerah dan atau waktu tertentu, tetapi tidak inovatif lagi di daerah dan atau waktu yang lain. 
Sementara pada aspek difusi teknologi, sering juga memerlukan waktu yang agak lama untuk dapat menerapkan oleh sasaran penyuluhan. Difusi inovasi dalam suatu penyuluhan perikanan perlu memperhatikan peta interaksi sosial dengan mengidentifikasi informal leaders dan peranannya dalam distribusi informasi dan teknologi kepada masyarakat.

Kecepatan tahap penerapan suatu inovasi yang disampaikan merupakan fenomena menarik, dikarenakan banyak faktor yang ikut mempengaruhinya. Di masyarakat faktor-faktor tersebut diantaranya faktor sugesti (pengaruh atau kepercayaan), identifikasi (penelaahan) serta faktor imitasi (peniruan), dan ciriciri dari inovasi yang disampaikan, serta gencarnya promosi dari inovasi tersebut. Disamping itu inovasi pembanding juga menjadi bagian dari pertimbangan dalam menerapkan satu inovasi. Pengguanaan probiotik untuk meningkatkan produksi ikan, kecepatan menerapkan tergantung pada perlakukan yang dilakukan oleh suatu sistem sosial. Membandingkan penggunaan karakteristik probiotik menjadi keputusan sistem sosial untuk menerapkan.

Penelitian ini bertujuan untuk:

1. Menganalisis kecepatan penerapan probiotik pendederan ikan patin.

2. Mengidentifikasi tahap karak- teritik probiotik yang diperkenalkan yang berhubungan dengan cepat atau lambat tingkat menerapkan terhadap probiotik yang diperkenalkan

3. Mengidentifikasi faktor internal maupun faktor ekternal pendederan ikan nila yang berhubungan dengan kecepatan menerapkan probiotik.

Penelitian ini diharapkan dapat memberikan manfaat dalam hal:

a) Memberikan kontribusi bagi pengembangan ilmu dan teknologi terutama yang berkaitan dengan difusi inovasi teknologi

b) Memberikan masukan dan saran bagi program penyuluhan terkait dengan materi dan metode penyuluhan.

Persepsi merupakan suatu proses yang didahului oleh penginderaan. Pengindraan adalah merupakan suatu proses diterimanya stimulus oleh individu melalui alat penerima yaitu alat indera. Namun proses tersebut tidak berhenti disitu saja, karena stimulus tersebut diteruskan oleh saraf otak sebagai pusat susunan saraf.

Karena itu proses persepsi merupakan suatu proses yang didahului alat indera. Alat indera merupakan penghubung antara individu dengan dunia luarnya. Proses Interaksi Sosial yang terlihat sederhana sebenarnya terjadi cukup 
kompleks. Beberapa faktor psikologik yang mendasari terjadinya persepsi dalam hubungan sosial meliputi: Faktor imitasi, yaitu proses meniru sesuatu untuk di-gunakan bagi diri sendiri atau kelompoknya; Faktor Sugesti, yaitu pengaruh psikis yang berasal dari diri sendiri atau dari orang lain dapat dibedakan menjadi meliputi auto sugesti, sugesti terhadap dirinya sendiri dan hetero sugesti, sugesti yang datang dari orang lain; Faktor Identifikasi, yaitu dorongan menjadi identik dengan orang lain;
Faktor Simpati, yaitu suatu perasaan tertarik kepada orang lain yang timbul atas dasar perasaan atau emosi, dan cenderung terjalin saling pengertian yang mendalam.

Kerangka pikir yang dibangun sebagai landasan penelitian ini adalah ingin melihat tingkat kecepatan menerapkan pada inovasi yang diperkenalkan dalam hal ini penggunaan probitiotik pada pendederan ikan patin pada sistem sosial masyarakat yang berada di wilayah Kecamatan Jatiluhur Kabupaten Purwakarta, Provinsi Jawa Barat.

Terdapat beberapa faktor yang berhubungan dengan tingkat menerapkan pada sistem sosial suatu kelompok.

\begin{tabular}{|l|l|}
\hline \multicolumn{1}{|c|}{ KARAKTERISTIK INTERNAL } & $\mathrm{X} 1$ \\
\hline Umur & $(\mathrm{X} 1-1)$ \\
\hline Tingkat Pendidikan Formal & $(\mathrm{X} 1-2)$ \\
\hline Pengalaman usaha Usaha & $(\mathrm{X} 1-3)$ \\
\hline Kekosmopolitan & $(\mathrm{X} 1-4)$ \\
\hline Keinovatifan & $(\mathrm{X} 1-5)$ \\
\hline KARAKTERISTIK PENDIFUSI & $\mathrm{X} 2$ \\
\hline Kridibilitas & $(\mathrm{X} 2-1)$ \\
\hline Empati & $(\mathrm{X} 2-2)$ \\
\hline Daya Tarik & $(\mathrm{X} 2-3)$ \\
\hline KARAKTERISTIK INOVASI & $\mathrm{X} 3$ \\
\hline Keuntungan relatif & $(\mathrm{X} 3-1)$ \\
\hline Kompatibilitas/keselarasan & $(\mathrm{X} 3-2)$ \\
\hline Kompleksitas/kerumitan & $(\mathrm{X} 3-3)$ \\
\hline Dapat Dicoba & $(\mathrm{X} 3-4)$ \\
\hline Bisa diamati & $(\mathrm{X} 3-5)$ \\
\hline
\end{tabular}

Gambar 1. Kerangka pikir dalam penelitian difusi adopsi teknologi 
Faktor-faktor tersebut yaitu faktor internal, faktor pendifusi dan karakteristik inovasi. Berdasarkan hal tersebut disusun suatu kerangka pikir seperti pada Gambar 1.

Hipotesis yang digunakan dalam penelitian ini adalah:

1. Terdapat hubungan yang nyata antara karakteristik internal dengan persepsi inovasi;

2. Terdapat hubungan yang nyata antara karakteristik pendifusi dengan persepsi inovas;

3. Terdapat hubungan yang nyata antara karakteristik inovasi dengan persepsi inovasi

\section{BAHAN DAN METODE}

Penelitian difusi ini dilakukan di areal Kecamatan Jatiluhur Kabupaten Purwakarta, Provinsi Jawa Barat. Penelitian dilakukan selama dua bulan, Maret-Mei 2016. Responden pada penelitian ini adalah 12 orang. Data yang dikumpulkan terdiri dari data primer dan data sekunder. Data primer dikumpulkan dengan wawancara kepada masyarakat sampel anggota kelompok di Buana Kahuripan sebagai lokasi kaji terpa inovasi probiotik. menggunakan daftar pertanyaan yang telah disiapkan, dan dilakukan juga wawancara mendalam (indepth interview) dengan ketua kelompok, Penyuluh Perikanan, dan Kepala Desa. Data sekunder dikumpulkan dari Balai Budidaya Ikan Patin dan lele Cijengkol.

\section{HASIL DAN PEMBAHASAN}

Kecamatan Jatiluhur memiliki dua kelompok pembudidaya ikan yang bergerak disegmen usaha pendederan ikan patin. Lokasi usaha budidaya ikan di Desa Cibi-nong berada jauh dari jalan raya sehingga terhindar dari kebisingan dan getaran ken-daraan, tempat lalu lalang orang, bebas ban-jir dan sesuai dengan tata ruang wilayah. Lokasi usaha juga jauh dari limbah pabrik maupun limbah rumah tangga yang dapat mencemari sumber air hingga menyebabkan kematian pada ikan budidaya. Lokasi usaha budidaya ikan tersebut dekat dengan sum-ber air yang kontinuitasnya bisa terjamin sepanjang tahun serta dibitnya cukup. Kara-kteristik sasaran penyuluhan merupakan salah satu faktor yang perlu diperhatikan dalam proses difusi inovasi. Bagan pe-rubahan dan kecenderungan jumlah pelaku utama pendeder ikan patin selama sembilan tahun seperti pada Tabel.1 Pelaku utama yang bergerak di bidang usaha pendederan ikan patin umumnya berusia lebih dari 40 tahun dengan tingkat pendidikan relativ rendah yaitu lulusan SD dan SMP dengan pengalaman budidaya lima sampai dengan 12 tahun. 
Tabel 1. Perubahan dan kecenderungan jumlah pelaku utama perikanan

\begin{tabular}{|c|c|c|c|c|c|c|c|}
\hline No & Anggota Kelompok & $\begin{array}{c}\text { Usia } \\
\text { (tahun) }\end{array}$ & Kategori & $\begin{array}{c}\text { Tingkat } \\
\text { Pendidikan }\end{array}$ & Kategori & $\begin{array}{c}\text { Pengalaman } \\
\text { Budidaya } \\
\text { (tahun) }\end{array}$ & Kategori \\
\hline 1 & Kusdiana & 47 & Sedang & 3 & Sedang & 12 & Lama \\
\hline 2 & Anda & 40 & Sedang & 4 & Tinggi & 5 & Sedang \\
\hline 3 & Syarip Hidayat & 30 & Muda & 3 & Sedang & 5 & Sedang \\
\hline 4 & Aja Jauhari & 43 & Sedang & 2 & Rendah & 4 & Sedang \\
\hline 5 & Deden Ruhyat & 48 & Sedang & 3 & Sedang & 12 & Lama \\
\hline 6 & Supian & 48 & Sedang & 3 & Sedang & 6 & Sedang \\
\hline 7 & Tarji Sutisna & 48 & Sedang & 3 & Sedang & 2 & Sedang \\
\hline 8 & Ahmad Bakri & 27 & Muda & 5 & Tinggi & 2 & Sedang \\
\hline 9 & Somad & 55 & Sedang & 2 & Rendah & 1 & Sedang \\
\hline 10 & Tanu & 54 & Sedang & 2 & Rendah & 5 & Sedang \\
\hline 11 & Udi Mukhtar & 45 & Sedang & 3 & Sedang & 2 & Sedang \\
\hline 12 & Anen & 62 & Tua & 2 & Rendah & 0,5 & Baru \\
\hline Juml & lah Rata-rata & $\begin{array}{l}547 \\
45,58\end{array}$ & - & ${ }^{35} \quad$ 2,92 & - & $\begin{array}{ll}56 & \\
& 4,67\end{array}$ & - \\
\hline & Standar Deviasi & 9,88 & - & 0,90 & - & 3,78 & - \\
\hline
\end{tabular}

Ket: Tidak Sekolah= 1; SD= 2; SMP/SLTP= 3; SMA/SLTA=4; Perguruan Tinggi= 5

Tabel 2. Karakteristik sasaran penyuluhan perikanan

\begin{tabular}{|c|c|c|c|c|c|c|c|c|c|}
\hline Kegiatan & 2008 & 2009 & 2010 & 2011 & 2012 & 2013 & 2014 & 2015 & 2016 \\
\hline $\begin{array}{l}\text { Pendederan } \\
\text { Ikan Patin }\end{array}$ & $\sqrt{ } \mathrm{V}$ & $\sqrt{ } \sqrt{ }$ & $\begin{array}{l}\sqrt{ } \sqrt{ } \sqrt{ } \sqrt{ } \\
\sqrt{ } \sqrt{ } \downarrow \sqrt{ }\end{array}$ & 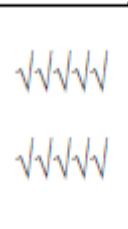 & 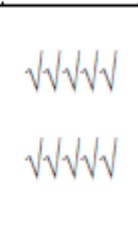 & 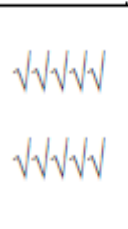 & 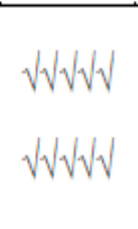 & $\begin{array}{c}\sqrt{ } \sqrt{ } \sqrt{V} \\
\sqrt{ } W \downarrow W \\
\sqrt{ }\end{array}$ & $\begin{array}{c}\sqrt{ } \sqrt{ } \sqrt{ } \\
\sqrt{ } \sqrt{ } \sqrt{ } \\
\sqrt{ }\end{array}$ \\
\hline
\end{tabular}

Keterangan: $\sqrt{ }=1$ orang pelaku utama

\section{Inovasi teknologi probiotik pada usaha pendederan ikan patin}

Kegiatan difusi inovasi teknologi probiotik pada usaha pendederan ikan patin dilaksanakan atas dasar rendahnya produksi benih ikan patin di Kecamatan Jatiluhur akibat rendahnya pengetahuan, sikap dan keterampilan pembudidaya akan inovasi teknologi perikanan seperti penggunaan probiotik pada usaha budidaya perikanan. Probiotik dalam akuakultur didefinisikan sebagai mikroba (jasad renik) yang sengaja diberikan melalui makanan maupun media (lingkungan) dan menguntungkan bagi makluk hidup, hewan budidaya. Manfaat penggunaan bahan probiotik juga untuk memperbaiki lingkungan, mencegah terjadinya penyakit, memperbaiki sistem pencernaan dan metabolisme ikan, dan membantu ikut meningkatkan jumlah makanan alami dan atau meningkatkan produktivitas. Bakteri pengisi probiotik yang digunakan sebagai percontohan dalam pelaksanaan kaji terap Jurnal Penyuluhan Perikanan dan Kelautan 
yaitu Lactobacillus. Bakteri Lactobacillus, usus, menekan bakteri yang merugikan, merupakan bakteri penghasil asam laktat, dan menghasilkan enzyme dan membantu hidup dalam kondisi lingkungan yang ku- proses pencernaan; selanjutnya meningrang oksigen. Sangat baik untuk campu- katkan vitalitas ikan. ran pakan. Lactobacillus ini hidup dalam

Tabel 3. Hasil kaji terap terhadap Kualitas Air Kolam Percontohan Budidaya

\begin{tabular}{|c|c|c|c|c|c|c|c|}
\hline \multirow{2}{*}{ No } & \multirow{2}{*}{$\begin{array}{c}\text { Minggu } \\
\text { Ke- }\end{array}$} & \multicolumn{2}{|c|}{ Kolam Perlakuan } & \multicolumn{4}{|c|}{ Kolam Tanpa Perlakuan } \\
\hline & & $\begin{array}{l}\text { Suhu } \\
\left({ }^{\circ} \mathrm{C}\right)\end{array}$ & $\mathrm{pH}$ & $\begin{array}{c}\text { DO } \\
\text { (ppm) }\end{array}$ & $\begin{array}{l}\text { Suhu } \\
\left({ }^{\circ} \mathrm{C}\right)\end{array}$ & $\mathrm{pH}$ & $\begin{array}{c}\mathrm{DO} \\
\text { (ppm) }\end{array}$ \\
\hline 1. & Tebar & 29,4 & 7,9 & 5,5 & 29,1 & 7,9 & 5,5 \\
\hline 2. & Minggu Ke-1 & 30,1 & 8,1 & 5,6 & 29,9 & 8,1 & 5,4 \\
\hline 3. & Minggu Ke-2 & 28,7 & 7,6 & 5,8 & 28,7 & 7,9 & 5,5 \\
\hline 4. & Minggu Ke-3 & 30,1 & 7,7 & 5,6 & 30,5 & 7,9 & 5,5 \\
\hline 5. & Minggu Ke-4 & 27,8 & 7,9 & 5,5 & 27,3 & 7,9 & 5,5 \\
\hline 6. & Minggu Ke-5 & 29,8 & 7,8 & 5,7 & 29,3 & 7,5 & 5,5 \\
\hline 7. & Panen & 29,2 & 7,9 & 5,6 & 29,2 & 7,9 & 5,5 \\
\hline & Jumlah & 205,1 & 54,9 & 39,3 & 204 & 55,1 & 38,4 \\
\hline & Rata-rata & 29,3 & 7,84 & 5,61 & 29,1 & 7,87 & 5,48 \\
\hline
\end{tabular}

Tabel 4. Hasil Monitoring Laju Pertumbuhan Kolam Percontohan Budidaya

\begin{tabular}{llccccccccc}
\hline No & \multirow{4}{*}{ Kolam Dengan Perlakuan } & \multicolumn{7}{c}{ Kolam Tanpa Perlakuan } \\
\cline { 2 - 10 } & $\begin{array}{c}\text { Panjang } \\
(\mathrm{cm})\end{array}$ & $\Delta$ & $\begin{array}{c}\text { Berat } \\
(\mathrm{g})\end{array}$ & $\Delta$ & $\begin{array}{c}\text { Panjang } \\
(\mathrm{cm})\end{array}$ & $\Delta$ & $\begin{array}{c}\text { Berat } \\
(\mathrm{g})\end{array}$ & $\Delta$ \\
\hline 1. & Tebar & 2,41 & - & 0,30 & - & 2,41 & - & 0,30 & - \\
2. & Minggu Ke-1 & 3,32 & 0,91 & 0,50 & 0,20 & 2,69 & 0,28 & 0,30 & 0,00 \\
3. & Minggu Ke-2 & 4,55 & 1,23 & 0,84 & 0,34 & 3,97 & 1,28 & 0,60 & 0,30 \\
4. & Minggu Ke-3 & 5,41 & 0,86 & 1,47 & 0,63 & 4,33 & 0,36 & 0,78 & 0,18 \\
5. & Minggu Ke-4 & 6,34 & 0,93 & 2,20 & 0,73 & 4,72 & 0,39 & 0,98 & 0,20 \\
6. & Minggu Ke-5 & 7,33 & 0,99 & 3,22 & 1,02 & 4,87 & 0,15 & 1,02 & 0,04 \\
7. & Panen & 7,81 & 0,48 & 3.90 & 0,68 & 5,17 & 0,30 & 1,16 & 0,14 \\
\hline & Jumlah & - & 5,40 & - & 3,60 & - & 2,76 & - & 0,86 \\
& & & 0,90 & - & 0,60 & - & 0,46 & - & 0,14 \\
\hline
\end{tabular}


Aplikasi probiotik yang diterapkan dimulai dari persiapan kolam hingga masa pemeliharaan baik melalui pakan maupun media budidaya (ling-kungan). Pemberian probiotik melalui pakan dilakukan dengan cara mencampur probiotik (probiotik cair yang dicampur air) dengan pakan secara mertair) dengan pakan secara merata sehingga probiotik terserap ke dalam pakan kemudian ditunggu sebentar sebelum diberikan kepada ikan. Difusi inovasi teknologi probiotik pada pendederan ikan patin dilaksanakan mulai tanggal 22 Februari 2016.

Tabel 5. Perbandingan Teknis Hasil Percontohan Budidaya

\begin{tabular}{clcc}
\hline No. & \multicolumn{1}{c}{ Parameter } & Kolam Perlakuan & $\begin{array}{c}\text { Kolam Tanpa } \\
\text { Perlakuan }\end{array}$ \\
\hline 1 & Ukuran Kolam (m) & $3 \times 4$ & $3 \times 4$ \\
2 & Jumlah Kolam (buah) & 1 & 1 \\
3 & Jumlah Benih (ekor) & 5.000 & 5.000 \\
4 & Jumlah Garam (kg) & 1 & 1 \\
5 & Jumlah Pakan (g) & 14.927 & 6.965 \\
6 & Probiotik (ml) & 222 & - \\
7 & Ukuran Panen (inci) & 3 & 2 \\
8 & Lama Pemeliharaan (hari) & 45 & 45 \\
9 & SR (\%) & 99,88 & 75 \\
10 & FCR & 0,83 & 2,46 \\
11 & Produksi (ekor) & 4.994 & 3.730 \\
12 & Produktivitas (ekor/m ${ }^{2}$ ) & 416 & 311 \\
\hline
\end{tabular}

Tabel 6. Tahap Menerapkan Inovasi Teknologi Probiotik

\begin{tabular}{|c|c|c|c|c|c|c|c|c|c|c|c|c|}
\hline \multirow{3}{*}{ No } & \multirow{3}{*}{ Kriteria } & \multicolumn{11}{|c|}{ Pengmenerapkan Pada Setiap Minggu } \\
\hline & & \multirow{2}{*}{$\begin{array}{l}\text { Feb } \\
\text { M1 }\end{array}$} & \multicolumn{4}{|c|}{ Maret } & \multicolumn{4}{|c|}{ April } & \multicolumn{2}{|c|}{ Mei } \\
\hline & & & $\mathrm{M} 2$ & $\mathrm{M3}$ & $\mathrm{M4}$ & M5 & H6 & M7 & M8 & M9 & $\mathrm{M} 10$ & M11 \\
\hline 1 & Sugesti & 9 & 3 & 3 & 5 & 5 & 4 & 9 & 9 & 9 & 6 & 5 \\
\hline 2 & Identifikasi & 2 & 5 & 4 & 3 & 3 & 4 & 5 & 4 & 4 & 7 & 8 \\
\hline 3 & Imitasi & 1 & 4 & 5 & 6 & 6 & 4 & 7 & 9 & 10 & 10 & 10 \\
\hline & Jumlah & 12 & 12 & 12 & 14 & 14 & 16 & 21 & 22 & 23 & 23 & 23 \\
\hline
\end{tabular}


Tabel 7. Nilai korelasi karakteristik internal pendifusi dengan persepsi

\begin{tabular}{clcc} 
No. & \multicolumn{1}{c}{ Parameter } & $\begin{array}{c}\text { Kolam dengan } \\
\text { perlakuan }\end{array}$ & $\begin{array}{c}\text { Kolam tanpa } \\
\text { perlakuan }\end{array}$ \\
\hline 1 & Biaya Tetap (Rp) & 182.084 & 182.084 \\
2 & Biaya Variabel (Rp) & 845.312 & 743.665 \\
3 & Biaya Total (Rp) & 1.027 .396 & 925.749 \\
4 & Pendapatan (Rp) & 1.498 .200 & 746.000 \\
5 & Keuntungan/Kerugian (Rp) & 470.804 & -179.749 \\
6 & BEP (Rp) & 413.827 & - \\
7 & BEP (unit) & 1.390 & - \\
8 & ROI (\%) & 78 & - \\
9 & R/C & 1,46 & 0,80 \\
10 & PP (hari) & 285 & - \\
\hline
\end{tabular}

Pelaksanaan dialakukan di unit usaha kelompok pembudidaya ikan Buana

Kahuripan Desa Cibinong Kecamatan Jatiluhur. Pada Tabel 5. Memperlihatkan bahwa kolam perlakukan probitik variabel SR, FCR, Produksi dan Produktivitas terlihat hasil yang baik.

Data Tingkat Persepsi Inovasi
Menurut Van Den Ban \& Hawkins (1999) kecepatan menerapkan inovasi dikarenakan beberapa hal yaitu memiliki keuntungan relatif yang tinggi bagi pembudidaya ikan, sesuai dengan nilainilai, pengalaman dan kebutuhannya, tidak rumit, dapat dicoba dalam skala kecil dan mudah diamati

Tabel 9. Nilai korelasi karakteristik internal pendifusi dengan persepsi

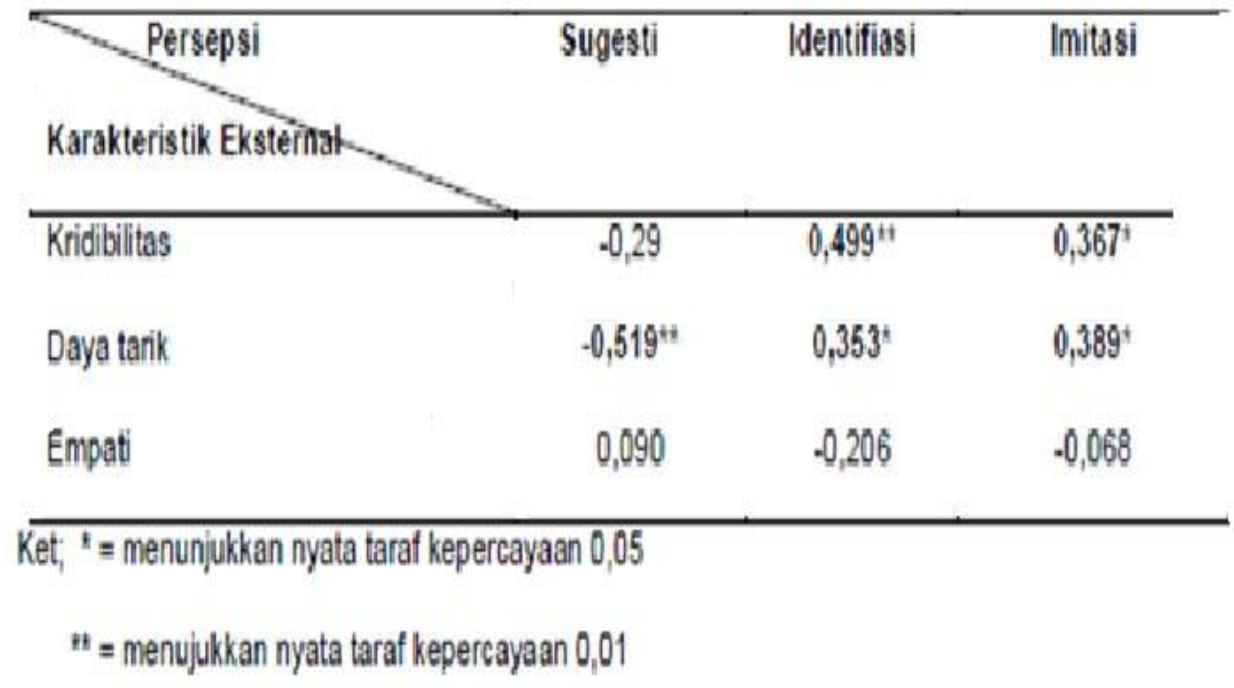


Tabel 10. Nilai korelasi karakteristik inovasi dengan tingkat menerapkan

\begin{tabular}{|c|c|c|c|}
\hline Karakteristik Inøvàti- & Sugesti & Identifikasi & Imitasi \\
\hline - Keuntungan relatif & $=0,090$ & $=0,122$ & $-0,495^{+}$ \\
\hline$>$ Kompatiblitas/keselaraean & $-0,309$ & $-0,173$ & $-0,655^{*}$ \\
\hline - Kompleksitas & $=0,343$ & $=0,459^{n+}$ & $=0,596^{\prime \prime}$ \\
\hline - Dapát Dicóbā & $-0,377$ & $0,441^{\prime}$ & $-0,585^{\prime \prime}$ \\
\hline - Bisa diamati & $.0,201$ & $0,379 r$ & $-0,524^{\prime \prime}$ \\
\hline
\end{tabular}

Sedangkan menurut Wiraatmadja (1978) sasaran dapat digolongkan menjadi Pelopor/innovator, Pengetrap dini atau early adopter, Pengetrap awal atau early majority, Pengetrap akhir atau late ma-jority, penolak atau laggard.

\section{Hasil Analisis Korelasi}

Hasil analisis nilai korelasi antara karakteristik internal pendifusi dengan Persepsi dapat dilihat pada Tabel 8, 9, 10 Nilai korelasi hubungan antara. Karak- teristik inovasi dengan tingkat menerapkan pada responden seperti pada Tabel 9. Analisis yang dilakukan antara karakteristik internal responden dengan karakteristik persepsi yang meliputi sugesti, identifikasi dan imintasi disajikan pada Tabel 8. Pada Gambar 3 menunjukkan bahwa pada karakteristik internal responden yang terkait kepada hubungan yang 


\begin{tabular}{|c|c|c|}
\hline KARAKTERISTIK INTERNAL (X1) & & \\
\hline Umur & $(\times 1-1)$ & --1 \\
\hline Tingkat Pendidikan Formal & $(\mathrm{X} 1-2)$ & -1 \\
\hline Pengalaman Usaha & $(x 1-3)$ & $\mathbf{T}$ \\
\hline Kekosmopolitan & $(X 1-4)$ & i \\
\hline Keinovatifan & $(\mathrm{X} 1-5)$ & 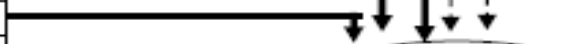 \\
\hline KARAKTERIS PRIBADI(X2) & & \\
\hline Kredibilitas & $(\times 2-1)$ & (Y) \\
\hline Daya Tarik & $(\times 2-2)$ & Sugesti (Y1) \\
\hline Empati & $(\times 2-3)$ & Identifikasi (Y2) \\
\hline KARAKTERISTIK INOVASI (X3) & & Imitasi (Y3) \\
\hline Keuntungan relatif & $(\mathrm{X} 3-1)$ & \\
\hline Kompatibilitas/keselarasan & $(x 3-2)$ & \\
\hline Kompleksitas/kerumitan & $(x 3-3)$ & \\
\hline Dapat Dicoba & $(x 3-4)$ & 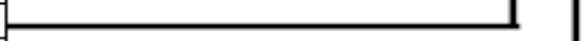 \\
\hline Bisa diamati & $(x 3-5)$ & \\
\hline
\end{tabular}

Gambar 3. Hasil kajian antara karakteristik internal dengan tingkat persepsi

erat dengan persepsi penggunaan probiotik terlihat adalah pengalaman usaha, kekosmopolitan dan keinovatifan. Semua karakteristik pribadi pendifusi memiliki hubungan yang erat dengan persepsi inovasi probiotik. Demikian juga lima atribut inovasi sangat erat dengan perspesi inovasi

\section{SIMPULAN}

1. Kecepatan Menerapkan pada kasus penelitian ini sangat ditentukan oleh Jenis Inovasi

2. Probitik merupakan jenis inovasi yang baru bagi masyarakat dan sangat dibutuhkan dalam pemecahan permasalah

3. Faktor yang mendukung kecapatapat menerapkan inovasi adalah orang yang mendifusikan inovasi dengan karakteristik memiliki kompetensi teknis, komunikasi serta memiliki kredibilitas, daya tarik dan empati yang tinggi.

\section{SARAN}

Penelitian difusi menerapkan inovasi perlu dilakukan pada kasus lain sehingga dapat membandingkan faktor pendukung maupun penghambatnya.

\section{DAFTAR PUSTAKA}

Donaldson L \& EE Scanel. 1992. Human resource development: teew trainer's guide. San Juan: Addison- Wesley Publishing Co. Inc.

Kerlinger FN. 2002. Asas -asas penelitian behavioral. Diterjemah kan oleh $\mathrm{R}$. Simatupang. Yogyakarta: Gajah mada Univer sity Press.

Laksana F. 2008. Manajemen pemasaran (pendekatan praktis). Graha Ilmu. Yogjakarta.

Lionberger HF \& PH Gwin. 1982. Communication strategies: a guide for agricultural change agents, danville, illiois: The Interstate Printers \& Publishers, Inc.

Nuraeni I. 2002.Diktat manajemen agribisnis. STP Bogor

Rahardi F. 2008. Agribisnis perikanan. Penebar Swadaya. Jakarta.

Runtuwarow V. 2002. Hubungan karakte- 
ristik personal dan komunikasi kelompok tani ikan dengan penerapan budidaya ikan mas sistem jaring apung di Danau Todano Minahasa, Sulawesi Utara" Tesis Program Pasca- sarjana, IPB.

Rogers EM, \& FF Shoemaker. 1987. Memasyarakatkan ide-Ide baru. Di- sarikan oleh Abdillah hanafi. Surabaya: Usaha Nasional.

Van den Ban \& HS Hawkins, 1998. Penyuluhan pertanian. Agnes D Herdiastuti, penerjemah. Terjemah an dari Agricuktural Extention (Second Edition). Kanasius Yogyakarta. 